\title{
Non-Timber Forest Products (NTFP) in the Brazilian Amazon and Cerrado biomes: multi scale governance for Implementing enhanced socio-biodiversity chains
}

\author{
Produtos florestais não madeireiros (PFNM) nos biomas \\ da Amazônia brasileira e do Cerrado: governança \\ multiescala para implementação de cadeias da \\ sociobiodiversidade
}

\author{
Sónia Maria Carvalho Ribeiro ${ }^{a}$ \\ Helder Lages Jardim ${ }^{b}$ \\ Úrsula Ruchkys de Azevedoc \\ Vagner Coelho \\ Laura Salles Bachi ${ }^{\mathrm{e}}$ \\ Britaldo Soares-Filho ${ }^{f}$
}

${ }^{a}$ Doutora em Ciências do Ambiente, University of East Anglia, Inglaterra, Professora do Departamento de Cartografia, Universidade Federal de Minas Gerais, UFMG, Belo Horizonte, MG, Brasil.

E-mail: sonia.carvalhoribeiro@gmail.com

${ }^{b}$ Doutor em Geografia Física, Universidade Federal do Rio de Janeiro, UFRJ, Professor Associado do Instituto de Geociências, Universidade Federal de Minas Gerais - UFMG,Belo Horizonte, MG, Brasil.

E-mail: hljardim@gmail.com

'Doutora em Geologia, Universidade Federal de Minas Gerais - UFMG, Professora Associada do Programa de Pós-graduação em Geografia e em Análise e Modelagem de Sistemas Ambientais,

UFMG, Belo Horizonte, MG, Brasil.

E-mail: tularuchkys@yahoo.com.br

${ }^{d}$ Doutor em Engenharia de Sistemas e Computação, Universidade Federal do Rio de Janeiro - UFRJ, Professor do Departamento de Cartografia, Universidade Federal de Minas Gerais, UFMG, Belo Horizonte, MG, Brasil. E-mail:vagnercoelho@hotmail.com

eDoutoranda do Programa de Pós-graduação em Análise e Modelagem de Sistemas Ambientais, UFMG, Belo Horizonte, MG, Brasil. E-mail: bachilaura@gmail.com

${ }^{f}$ Doutor em Engenharia de Transportes, Universidade de São Paulo - USP, Professor do Departamento de Cartografia, Universidade Federal de Minas Gerais, UFMG, Belo Horizonte, MG, Brasil.

E-mail: britaldossf@gmail.com

doi:10.18472/SustDeb.v11n2.2020.28393 


\begin{abstract}
Non-Timber Forest Products (NTFP), contribute to the livelihoods of over 6 million people in Amazon and over 4 million people in the Cerrado biomes. Here we explored data on the socio-ecology of extractivist landscapes at the biome scale in Amazonia and Cerrado in Brazil. We found that there are market chains for 45 and 58 NTFPs in Brazilian Amazon and Cerrado, respectively. Although there is a vast repertoire of empirical data for characterizing sociobiodiversity in Brazil this body of literature is mostly case-study driven, focusing on a very limited number of products and using different methodological approaches. Therefore, although there is a robust research legacy meaningful comparisons are very challenging. So far we have a fragmented view of vegetal extractivist dynamics at the biome scale. Our work contributes to upscale from the socioecology of individual NTFP to the biome scale encompassing a variety of products and its associated livelihoods.
\end{abstract}

Keywords: Extractivist landscapes. Socio-Ecological Systems. Sustainable use. Sociobiodiversity.

\title{
RESUMO
}

Os produtos florestais não madeireiros (PFNM) contribuem para a subsistência de mais de 6 milhões de pessoas nos biomas da Amazônia e mais de 4 milhões de pessoas do Cerrado. Aqui exploramos dados sobre a socioecologia de paisagens extrativistas nos biomas da Amazônia e Cerrado no Brasil. Descobrimos que existem cadeias de mercado para 45 e 58 PFNM na Amazônia brasileira e no Cerrado, respectivamente. Embora exista um vasto repertório de dados empíricos para caracterizar a sociobiodiversidade no Brasil, a literatura sobre este tema é principalmente orientada por estudos de caso, concentrando-se em um número muito limitado de produtos e utilizando diferentes abordagens metodológicas. Portanto, embora exista um legado de pesquisa robusto, as comparações significativas são muito desafiadoras. Até agora, temos uma visão fragmentada da dinâmica extrativista vegetal na escala do bioma. Nosso trabalho contribui para melhorar a escala individual da socioecologia de PFNM para a escala do bioma, abrangendo uma variedade de produtos e seus meios de subsistência associados.

Palavras-chave: Paisagens extrativistas. Sistemas Socioecológicos. Uso Sustentável. Sociobiodiversidade.

\section{INTRODUCTION}

Cerrado and Amazon biodiversity in Brazil live together with a variety of sociocultural groups: over 644,000 families of ribeirinhos ${ }^{1}$ agro-extractivists, 204 indigenous tribes of over 605,000 families and over 4,500 families of Quilombolas ${ }^{2}$, creating a rich cultural heritage, singular Traditional Ecological Knowledge (TEK), and skilled traditional abilities. In Brazil, these traditional communities' use and trade raw materials of surrounding Amazon forests and Cerrado biomes as part of their livelihoods. These raw materials thereafter referred to as Non Timber Forest Products (NTFP), have been for centuries contributing to traditional livelihoods both for family consumption and trade. Despite decades of a prolonged debate on the role of the Non Timber Forest Products (NTFP) in contributing to traditional livelihoods as well as to reduce deforestation (PETERS, GENTRY et al. 1989, HUMPHRIES, HOLMES et al. 2012) a number of paradoxes remain. Historically, the appeal of these products (e.g. rubber) as an development option has faded with failure as was the utopian case of Fordlandia (Grandin 2010). The linkages between extractivist activities and conservation of biodiversity is fragile (Homma 2008), and a number of threats remain for example to the sustainability of Brazil nut collection (Peres, Baider et al. 2003).

Although acknowledging the challenges involved on the use and trade of NTFP, still nowadays, those products contribute to the livelihoods of over 6 million people in Amazon and over 4 million people ${ }^{3}$ in the Cerrado biomes. These traditional livelihoods in addition to collection of NTFP also include small 
scale farming and agro husbandry. One of the problems is that those products that are part of traditional livelihoods are associated to a lower capacity to generate household income. Often, as extractivist products enter the world market as "commodities", the market value of these raw-materials collected in native Amazonian forests or cerrado savannas is low, when compared from estimates based in local markets (Peters, Gentry et al. 1989). Moreover rents from extractivist activities of NTFP are eclipsed either by products originating in intensive cultivation processes in other parts of the world (e.g. rubber monocultures in China) or by other higher income activities such as cattle ranching associated to deforestation (e.g. cattle grazing) and "cowboy" imagery (Carvalho Ribeiro, Soares Filho et al. 2018).

Aware of the limitations on keeping native vegetation standing while contributing to socio ecological developments, Government policies and civil society alike, often in collaboration to International players (such as World Bank, FAO, European Union) have been encouraging management plans for those products to both conserve native vegetation and ensuring traditional livelihoods. In most of the cases, the development of management plans (for example of sustainable use reserves), is based on bottom up participatory processes involving traditional communities often associating to programs of Payment for Ecosystem Services (PES) (Wunder, Angelsen et al. 2014). In parallel, for overcoming this "NTFP market failure", raw materials and low-processed products collected and traded by extractivists have been nurtured by governments' worldwide and civil society alike. These products were awarded in 2009 as formal recognition of Brazilian Socio-biodiversity (MMA 2009). Despite decades of public investment and very rich body of "local" case studies and participatory management plans, little is yet known as how to frame governance arrangements for extractivist landscapes in biomes such as Amazonia and Cerrado.

This work aims at exploring and draws a reflection on possible ways for framing governance for traditional extractivist livelihoods in biomes such as Amazonia and Cerrado. This paper explores possible multiscale governance strategies that may contribute to overcome the dilemmas of extractivist activities in Brazil. This work advances the state of the art by including non-material goods associated with these products, for example, landscape identity and traditional local knowledge (TEK Traditional Ecological Knowledge) through its association with cultural ecosystem (Carvalho Ribeiro, Soares Filho et al. 2018).

The results present the characterization and mapping of the sociobiodiversity associated to vegetal extractivism in the Brazilian Amazon and Cerrado using a unique conceptual model of the Multilevel Perspective [6]. According to the typology of Sociotechnical Transitions (Geels \& Schot, 2007), we consider the diversity of products in each biome as a socio technical regime (Figure 1). Following this framework, each biome is considered as a socio technical regime with its diversity of products, however to analyze its diversity of production systems we will explore only two products in each biome. We particularly focus on four NTFP, two in Cerrado and two in Amazon biomes. One product is of wide and another narrow scope in terms of geographical distribution. Our major goal is to specify which governance mechanisms (bottom up and top down) can improve the transition to sustainability in extractivist landscapes in two of the most emblematic biomes in Brazil.

The questions we address are as follows:

I. Which sources of literature refer to the diversity of NTFPs in Cerrado and Amazon?

II. Which are major characteristics of the Amazon and Cerrado socio technical regimes concerning: Productive cycles species/productivity (tons per ha), seasonality, Markets, Technology used Norms \& Politics, Traditional Ecologycal Knowledged (TEK) associated and Science, research \& development

III. Which multiscale governance mechanism can lead extractivist landscapes in Amazon and Cerrado biomes towards sustainability? 


\section{METHODS}

\subsection{CONCEPTUAL FRAMEWORK}

We use a unique conceptual model of the Multilevel Perspective for analyzing Amazon and Cerrado Biomes. According to the typology of Socio-Technical Transitions (Geels 2011, Geels \& Schot, 2007), we consider the diversity of products in each biome as a socio technical regime (Figure 1). At the bottom of the socio technical regime, and in order to transform the socio technical regime to a more sustainable state, there might be niche innovations that may lead the regime to a sustainable transition. Those niche innovations can increase momentum through the learning process as well as bottom up performance improvements.

These bottom-up innovations can eventually pressure "socio-technical regimes". When pressure is placed on Socio-Technical Regimes, it creates "windows of opportunity" for niche innovations. However, not all niche innovations and innovative technologies will be able to become part of the new regime without the influence of the external player (often top down processes). In many cases the transition to sustainability occurs when bottom up niche innovations are reinforced by top-down external factors such as finance, legislation or education.

\section{Increasing structuration of activities in local practices}

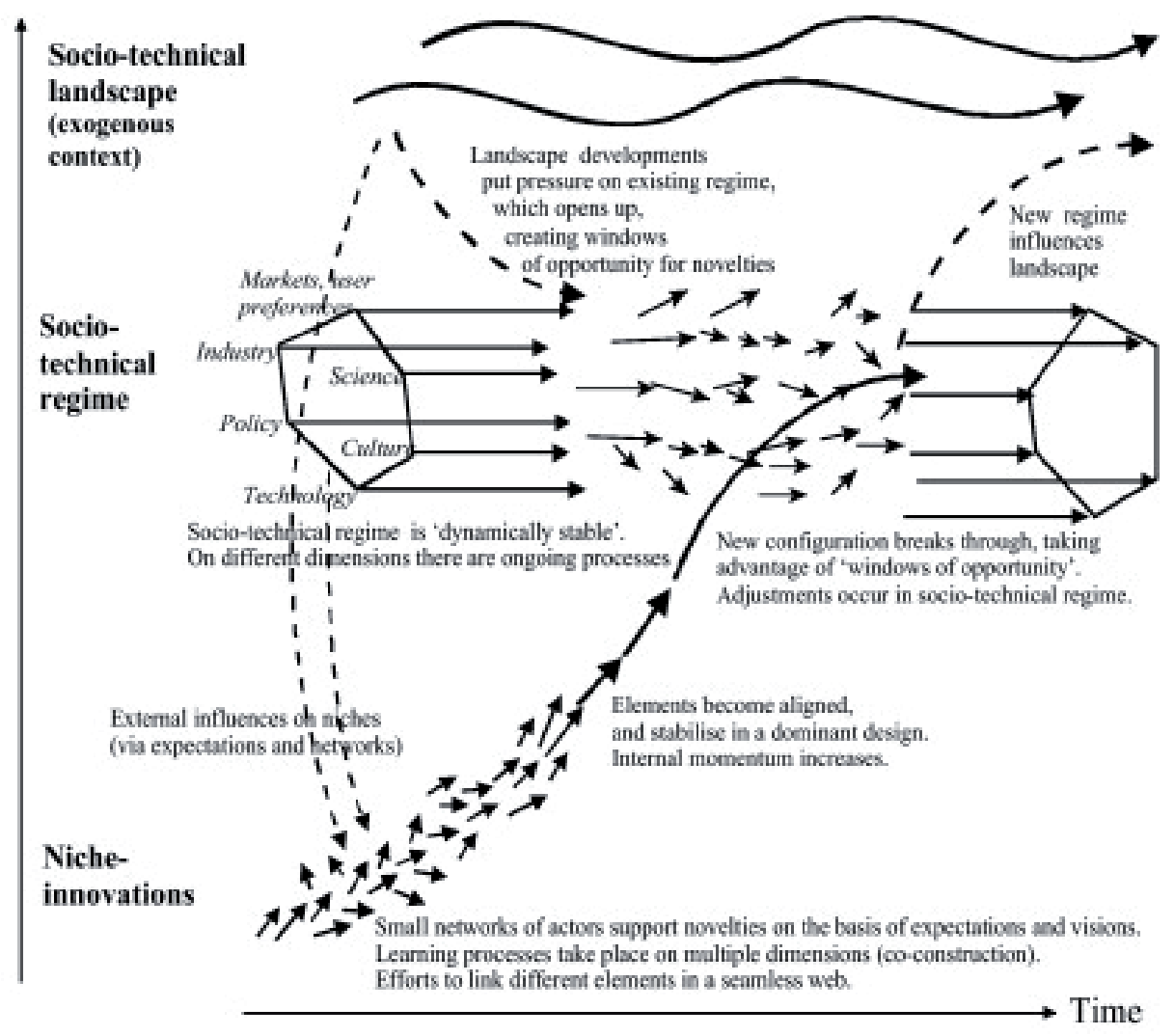

Figure 1 | Multi Level Perspective.

Source: Geels (2011).

We analyze each biome (Amazon and Cerrado) as a Socio-Technical regime and we explore Productive cycles of NTFP, Markets, Technologies, Policies Culture and Traditional Ecological Knowledge (TEK) and finally Science, research \& development. 


\subsection{DATA COLLECTION AND LITERATURE REVIEW}

After defining the conceptual framework, we collected data from Governmental and Non-Governmental organizations able to describe the dynamics of extractivist products in Brazil. We started by downloading data from IBGE and from the Ministry of Environment concerning the Sociobiodiversity chains (MMA, 2009). Based on the names of the municipalities and its NTFPs we assess the geographical distribution of the sociobiodiversity chains in Brazil (Figure 2). We also reviewed literature able to systematize the 6 characteristics of the sociotechnical regime described in 2.1 above but also for exploring both "Niche Innovations" and the "Socio Technical Landscape", as shown in Figure 1. Niche innovations concern small scale initiatives that are likely able to transform the regime. As niche innovations we describe local initiatives developing in the last 20 years. We aim at capturing number of initiatives and its driving forces as well as the type of actors developing these initiatives. The major goal is to assess evidence of whether or not niche innovations in place can lead the Socio-Technical Regime towards a sustainable transition. We will also look for evidences for characterizing the Socio-Technical Landscape and explore whether or not there are top down initiatives likely to lead extractivist Socio-Technical Regimes into a sustainable transition. Our review includes both scientific papers and grey literature. We review work published from 2008 to 2018 (supplementary material 1 lists all the documents reviewed)

\section{RESULTS}

\subsection{DATA SOURCES AND LITERATURE REFERRING TO THE DIVERSITY OF NTFPS IN CERRADO AND AMAZON}

The Brazilian statistics office IBGE (Instituto Brasileiro de Geografia e Estatística) reports data on production (in tons) and values of production (in thousand reais of 33 Non Timber Forest Products - NTFP), which are organized into 6 different categories: Rubber, Waxes, Fiber, Tenants, Oils, Food, Aromatic and Medicinal (Table 1). Shaded in Table 1 are the products awarded as Sociobiodiversity chain ${ }^{4}$. The IBGE data set is based on municipal reports and does not explicitly refer to the products of vegetal extractivist activities by biome.

Table 1 | NTFP organized into six IBGE categories.

\begin{tabular}{|c|c|c|c|c|c|c|}
\hline Rubber & Waxes & Fiber & Tanantes & Oils & Food & Aromatic/medic. \\
\hline $\begin{array}{l}\text { Hévea } \\
\text { (coagulated } \\
\text { latex) }\end{array}$ & $\begin{array}{l}\text { Carnaúba } \\
\text { (wax) }\end{array}$ & Buriti & Angico (shell) & $\begin{array}{l}\text { Babaçu } \\
\text { (almond) }\end{array}$ & Açaí (fruit) & Jaborandi (leaf) \\
\hline $\begin{array}{l}\text { Hévea (liquid } \\
\text { latex) }\end{array}$ & $\begin{array}{l}\text { Carnaúba } \\
\text { (powder) }\end{array}$ & Carnaúba & $\begin{array}{c}\text { Barbatimão } \\
\text { (shell) }\end{array}$ & Copaíba (oil) & $\begin{array}{l}\text { Castanha de } \\
\text { caju }\end{array}$ & Urucu (seed) \\
\hline Maçaranduba & Others & Piaçava & Others & $\begin{array}{l}\text { Cumuru } \\
\text { (almond) }\end{array}$ & $\begin{array}{l}\text { Castanha-do- } \\
\text { Pará }\end{array}$ & Others \\
\hline \multirow[t]{5}{*}{ Sorva } & & Other & & $\begin{array}{c}\text { Licuri } \\
\text { (coconut) }\end{array}$ & Erva-mate & \\
\hline & & & & Oiticica (seed) & $\begin{array}{l}\text { Mangaba } \\
\text { (fruit) }\end{array}$ & \\
\hline & & & & $\begin{array}{c}\text { Pequi } \\
\text { (almond) }\end{array}$ & Palmito & \\
\hline & & & & $\begin{array}{l}\text { Tucum } \\
\text { (almond) }\end{array}$ & Pinhão & \\
\hline & & & & Others & Umbu (fruit) & \\
\hline
\end{tabular}

NTFP shaded are included into the Socio Biodiversity plan by (MMA 2009).

Source: IBGE (2015). 
In addition to IBGE data, the National Plan for promoting the sociobiodiversity chains developed by the Ministry of environment in 2009 , lists the names of the municipalities that were awarded by the sociobiodiversity program and the product that was selected in each municipality (called in portuguese "territórios da cidadania"). Based on this data we were able to analyze the spatial distribution of the sociobiodiversity chains in Brazil (Figure 2). As can be seen in Figure 2 infographic the majority of the municipalities comprising the sociobiodiverity plan are located in the Northwest of the country notably in Amazonia.
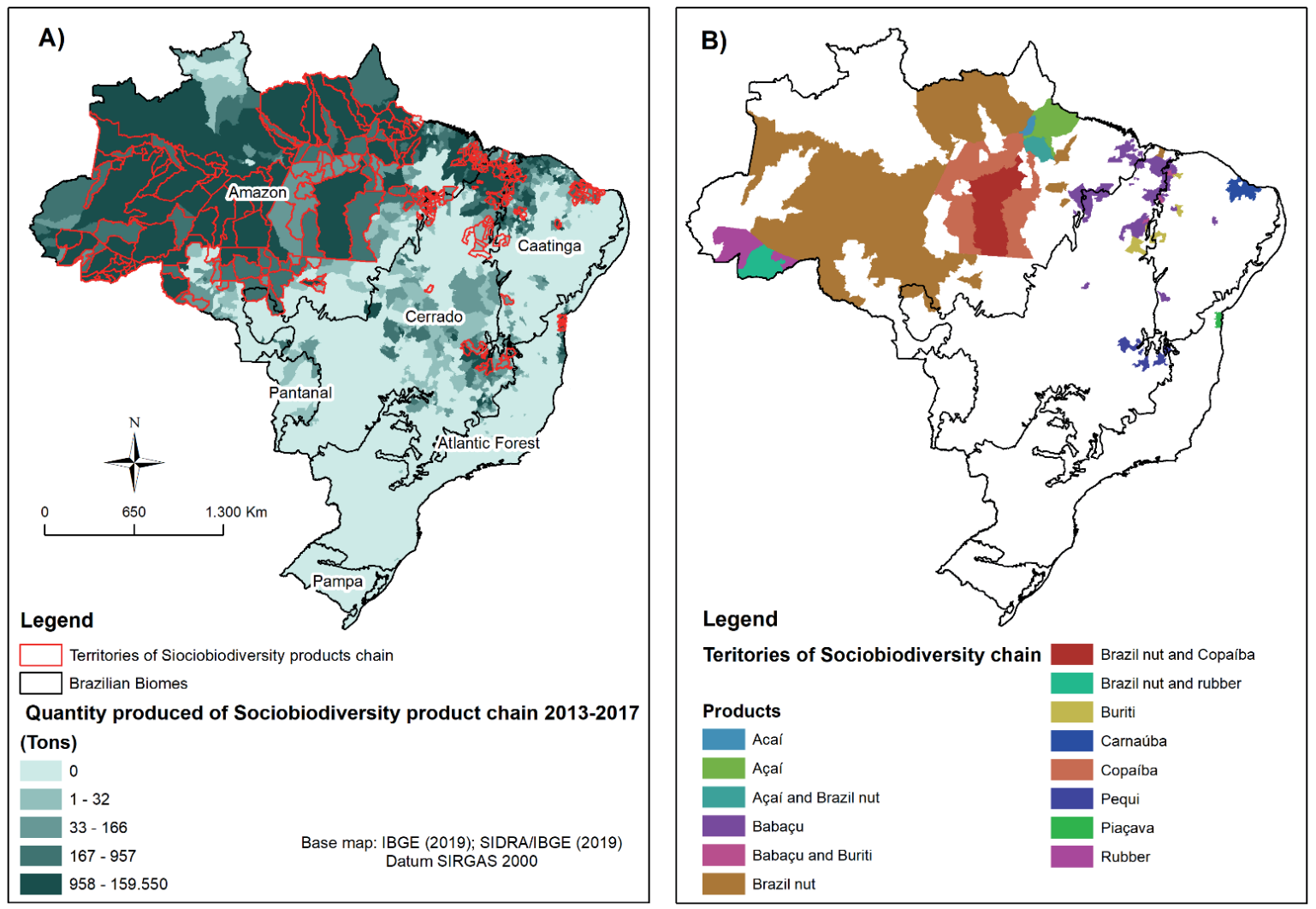

Figure 2 | National Plan of Sociobiodiversity plan, A) quantity produced of sociobiodiversity products chain (e.g. Açaí, Brazi nut, Rubber, Pequi, Babaçu, Andiroba, Carnaúba, Buriti, Copaíba and Piaçava) between the year of $2013-2017$ and B) spatial distributions of the products chains.

Source: survey data (2019).

\subsection{NON-TIMBER FOREST PRODUCTS IN THE CERRADO BIOME}

The second largest biome in Brazil, the Cerrado covers an area of 2 million km2, corresponding to 204 million hectares. This represents almost a quarter of the country's total land area. Notwithstanding being home of about 46 million inhabitants Cerrado is considered a biodiversity hotspot holding about 12,000 species of plants (trees, shrubs, herbs and vines), 251 species of mammals, 856 species of birds, 262 species of reptiles, 209 species of amphibians, 800 species of fish, which partially shows the richness of this biome. However, only $8.3 \%$ of the cerrado is protected. Deforestation has been steadily occurring and as a consequence of this deforestation, several species of fauna (266) and flora (637) are already threatened by extinction (Embrapa, 2019). Cerrado, has several subtypes and fitophisionomies (campo sujo, campo limpo, cerradão), which are dependent on soil types, relief, groundwater, etc., results in a great variety of products, the collection of which sustains many inhabitants of this biome (Table 2). 
Table 2 | Fruits from Cerrado biome and scientific names.

\begin{tabular}{|c|c|c|}
\hline ID & Fruit & Scientific name \\
\hline 1 & Amora-Preta & Bubus cf brasilliensis \\
\hline 2 & Ananás & Annas ananassoides \\
\hline 3 & Araçá & Psidium firmum \\
\hline 4 & Araticum & Annona crassiflora \\
\hline 5 & Araticum-de-Casca-Lisa & Annona coriacea \\
\hline 6 & Araticum-Rasteiro & Annona pygmaea \\
\hline 7 & Araticum-Tomentoso & Annona cf. tomentosa \\
\hline 8 & Babaçu & Orbygnia cf. phalerata \\
\hline 9 & Bacupari & Salacia campestris \\
\hline 10 & Banha-de-Galinha & Swartzia langsdorfii \\
\hline 11 & Baru & Dypterix alata \\
\hline 12 & Buriti & Mauritia vinifera \\
\hline 13 & Cagaita & Eugenia dysenterica \\
\hline 14 & Cajuzinho-do-Cerrado & Spondia cf. lutea $L$. \\
\hline 15 & Caju-de-Árvore-do-Cerrado & Anacardium othonianum \\
\hline 16 & Caju-Rasteiro & Anacardium pumilum \\
\hline 17 & Cajuzinho-do-Cerrado & Anacardium humile \\
\hline 18 & Chichá & Sterculia striata \\
\hline 19 & Coquinho-do-Cerrado & Syagrus flexuosa \\
\hline 20 & Croadinha & Mouriri elliptica \\
\hline 21 & Curriola & Pouteria ramiflora \\
\hline 22 & Fruto-do-Tatu & Crhysophyllum soboliferum \\
\hline 23 & Gabiroba & Campomanesia cambessedeana \\
\hline 24 & Gravatá & Bromelia balansae \\
\hline 25 & Guapeva & Pouteria cf. gardineriana \\
\hline 26 & Guariroba & Syagrus oleraceae \\
\hline 27 & Ingá-do-Cerrado & Inga laurina Willd.. \\
\hline 28 & Jaracatiá & Jacaratia hiptaphylla \\
\hline 29 & Jatobá-do-Cerrado & Hymenaea stigonocarpa \\
\hline 30 & Jatobá-da-Mata & Hymenaea stilbocarpa \\
\hline 31 & Jenipapo & Genipa ameriacana \\
\hline 32 & Jerivá & Syagrus romanzoffiana \\
\hline 33 & Lobeira & Solanum lycocarpum \\
\hline 34 & Macaúba & Acrocomia aculeata \\
\hline 35 & Mama-Cadela & Brosimum gaudichaudii \\
\hline 36 & Mangaba & Hancornia spp. \\
\hline 37 & Maracujá-de-Cobra & Passiflora coccinea \\
\hline 38 & Maracujá-do-Cerrado & Passiflora cincinnata \\
\hline 39 & Maracujá-Doce & Passiflora alata \\
\hline 40 & Maracujá-Nativo & Passiflora eichleriana \\
\hline 41 & Maracujá-Roxo & Passiflora edulis \\
\hline 42 & Marmelada-de-Bezerro & Alibertia edulis \\
\hline 43 & Marmelada-de-Cachorro & Alibertia sessillis \\
\hline 44 & Marmelada-de-Pinto & Alibertia elliptica \\
\hline 45 & Melancia-do-Cerrado & Melancium campestre \\
\hline 46 & Murici & Byrsonima verbascifolia \\
\hline 47 & Palmito-da-Mata & Euterpe adulis \\
\hline
\end{tabular}




\begin{tabular}{|c|c|c|}
\hline ID & Fruit & Scientific name \\
\hline 48 & Pequi & Caryocar brasilliense \\
\hline 49 & Pequi-Anão & $\begin{array}{c}\text { Caryocar brasilliense (subsp. } \\
\text { Intermedium) }\end{array}$ \\
\hline 50 & Pêra-do-Cerrado & Eugenia klostzchiana \\
\hline 51 & Perinha & Eugenia lutescens \\
\hline 52 & Pimenta-de-Macaco & Xilopia aromatica \\
\hline 53 & Pitanga-Vermelha & Eugenia calycina \\
\hline 54 & Pitomba-do-Cerrado & Talisia esculenta \\
\hline 55 & Puçá & Mouriri pusa \\
\hline 56 & Saputá & Salacia elliptica \\
\hline 57 & Tucum-do-Cerrado & Bactris spp. \\
\hline 58 & Uva-Nativa-do-Cerrado & Vitis spp. \\
\hline
\end{tabular}

Source: http://www.centraldocerrado.org.br/categoria/frutos/

In general, some of the products are endemic to the type of Cerrado in which they are found and others are spread throughout the territory occupied by this biome. Below we list Cerrado main products.

\subsubsection{THE PRODUCTS OF THE CERRADO}

The cerrado in all its forest formations provides an enormous amount of fruit and extractive products and many local communities rely on the raw materials "in natura" collection of fruits such as pequi, cagaita, ata, baru, bacuri, mangaba, buriti, among many other products. These products are usually traded in local markets of the regions where they are collected either raw or slightly processed by agroindustries, such as the production of frozen pulps, ice creams, jellies, jellies, dehydrated fruits, biscuits, cakes, pies, cosmetics and medicines (SEBRAE, 2013). Due to the huge diversity of Cerrado products, we focus in only two: Pequi and sempre vivas, one product of wider scope and other geographically restricted, respectively.

\section{PEQUI}

Pequi (Cariocar rasiliense camb) is a native fruit of the Brazilian cerrado. There are diverse types of using pequi. Pequi can be simply boild and used in the preparation in several dishes, jelly, sweets, liqueurs, and oils. The oils are also used in cosmetic and pharmacy industry (Oliveira, 1988, apud Oliveira et al (2008)). From its core can also be extracted an oil used in biodiesel (Peres 2019). However, in order to make up for this, there is a need for time and investment for the development of the technology. Nevertheless, the oil has been already tested in the composition of biofuels and the National Petroleum Agency has already authorized the mixture of biofuel extracted from pequi in official cars of some Brazilian Universities (USP, 2005). Pequi wood is also considered to be of good quality and highly resistant. However, since there are no programs to manage and use the specie on a sustainable basis, when cutting off the trees, it can cause irreparable damages to the ecosystems. Pequi bark can produce tannin and a kind of dark brown tincture used in artisan dyeing (Ribeiro et al, 1982). It also has many fibers, and can be used in human and bovine (has a quantity of protein, among other characteristics, much higher than that of wheat flour). Other uses and properties of Pequi have been investigated (Passos et al, 2002), such as the antimycotic effects found in leaves and seeds.

\section{SEMPRE VIVAS}

Sempre vivas are different species of plants that preserve its natural and dry appearance for long periods of time. Giulietti et al. (1996) highlight the following species of five monocotyledon families: Eriocaulaceae, Poaceae (Gramineae), Xyridaceae, Cyperaceae and Rapateaceae. Sempre vivas, refer to species whose external morphology resembles a "daisy" (all of the family Eriocaulaceae) and "buds", (Moreira, 2010). 
Sempre vivas occur in the Cerrado Biome distributed in the Southeast and Center-West regions of Brazil. The greatest diversity is in the tops of mountainous regions, at altitudes above 900 meters where rocky fields associated with rocky outcrops of quartzite, sandstone or iron formations occur - in the latter case under the name of ferruginous fields. Sempre vivas are occurring in the rupestrian fields of the highlands of the Espinhaço Range (MG and BA) and in the mountains of Goiás (Giulietti et al., 1996) and Tocantins.

One of the most important production and commercialization center is the municipality of Diamantina (MG) (Giulietti et al., 1988) and Jalapão (TO) where the species Syngonanthus nitens known as "golden grass" is marketed (Shmidt, 2005). They grow in different edaphic conditions, inhabiting dry, moist and even flooded soils, but always exposed to the sun (Scatena et al., 1999).

The harvest of sempre vivas is carried out during various periods of the year depending on the species. It is made by traditional communities, and it is common to find entire families in the field doing this activity during the flowering season. In Minas Gerais and Bahia, the most difficult areas to reach involve the displacement of groups of collectors who camp up to three months in the highlands during the entire flowering period. In the Jalapão region of Tocatins, the golden grass is collected by women, men and children in wet fields, adjacent to the trails, between July and October. The harvest is done by pulling the extremity of the flower (Shmidt, 2005). As in Minas Gerais and Bahia, harvesting sites may be close to houses or more distant. In all cases the collected material does not undergo any specific treatment, being gathered in small bundles, tied, and arranged in places to dry.

The extractive management is centered on the collection and burning of the humid fields in order to maximize production by manipulating the productive effort of the target plants (Shimidt, 2005; Bedê, 2006). Production is believed to be larger one year after the burning of the moist field. The management of this extractivist product can affect the demography of native populations in different ways, according to the part of the plant collected, quantities and time of collection, among other factors that may contribute to the decline of the productivity of the species (Ticktin 2004). In fact, uncontrolled exploitation impairs the recovery of natural populations, putting species with a more restricted geographical distribution at risk of extinction (Giulietti et al., 1988).

There are records of the commercialization of sempre vivas from the Serra do Espinhaço region in Minas Gerais since the 1930s. There is also records of shipping them to Vienna in Austria in 1935 (InstitutoTerra Brasilis, 1999). In the Jalapão region, commerce began in the mid-1990s, when it became known for the scenic beauty that attracted tourists, leading to the dissemination of handicrafts made with golden grass, until then produced on a small scale for use by the black community of Mucamba (Shmidt, 2005).

The five most frequently traded species of Minas Gerais, Bahia and Goiás are used for ornamental use, due to their beauty and durability, in interior decoration (Giulietti et al., 1996). Due to its malleability the golden grass is used to make baskets hats, bags, earrings by means of a technique of sewing small sauces with buriti silk in concentric bundles (Shmidt, 2005).

\subsubsection{NON-TIMBER FOREST PRODUCTS IN THE BRAZILIAN AMAZON}

Amazonia legal covers an area of 5, 2 million $\mathrm{km} 2$, this representing $61 \%$ of Brazil land area. Amazon biome only covers 4,2 million $\mathrm{Km} 2$ about $49 \%$ of Brazilian land of which 2,2 million $\mathrm{Km} 2$ are protected lands. According to the last IBGE census Legal Amazon is home to about 23 million inhabitants.

It is scarce the literature referring to the total number of NTFPs in the Brazilian Amazon (Table 3). INPA reports that there are 45 native NTFPs in the Amazon, 38 of which are traded in Manaus local markets (IMPA, 2012). According to IBGE (IBGE 2015), 30 out of 33 NTFPs found in Brazil occur in the Amazon region. From the 33 NTFPs reported by IBGE we could not find any record for Umbú, Pinhão and Erva Mate. 
Table 3 | Fruits from Amazon biome and scientific names.

\begin{tabular}{|c|c|c|}
\hline$I D$ & Fruit & Scientific name \\
\hline 1 & Abiu & Pouteria caimito) \\
\hline 2 & Açaí-solteiro & Euterpe precatoria \\
\hline 3 & Açaí-do-Pará & Euterpe oleracea \\
\hline 4 & Araçá-boi & Eugenia stipitata \\
\hline 5 & Bacaba & Oenocarpus bacaba \\
\hline 6 & Bacabí & Oenocarpus mapora \\
\hline 7 & Bacuri & Garcinia \\
\hline 8 & Biribá & Rollinia mucosa \\
\hline 9 & Buriti & Mauritia flexuosa \\
\hline 10 & Cacau & Theobroma cacao \\
\hline 11 & Cacau-da-mata & Theobroma sylvestre \\
\hline 12 & Caiaué & Elaeis oleifera \\
\hline 13 & Caju & Anacardium occidentale \\
\hline 14 & Cajuaçu & Anacardium spruceanum \\
\hline 15 & Castanha-de-cutia & Acioa edulis \\
\hline 16 & Castanha-do-Brasil & Bertholletia excelsa \\
\hline 17 & Castanha-sapucaia & Lecythis pisonis \\
\hline 18 & Cupuaçu & Theobroma grandiflorum \\
\hline 19 & Cumaru & Dipteryx odorata \\
\hline 20 & Guaraná & Paullinia cupana \\
\hline 21 & Inajá & Maximiliana maripa \\
\hline 22 & Ingá-chichica & Inga alba \\
\hline 23 & Ingá-cipó & Inga edulis \\
\hline 24 & Ingá-peluda & Inga macrophylla \\
\hline 25 & Ingaí & Inga laurina \\
\hline 26 & Jenipapo & Genipa americana \\
\hline 27 & Mapati & Pourouma cecropiifolia \\
\hline 28 & Mari-da-terra firme & Cassia grandis \\
\hline 29 & Moela-de-mutum & Lacunaria jenmanii \\
\hline 30 & Murici & Byrsonima chrysophylla \\
\hline 31 & Pajurá & Couepia bracteosa \\
\hline 32 & Patauá & Oenocarpus bataua \\
\hline 33 & Pitomba & Talisia esculenta \\
\hline 34 & Pupunha & Bactris gasipaes \\
\hline 35 & Pupunha-de-porco & Syagrus inajai \\
\hline 36 & Puruí & Borojoa sorbilis \\
\hline 37 & Sapota-do-Solimões & Quararibea cordata \\
\hline 38 & Sorvinha & Couma utilis \\
\hline 39 & Taperebá & Spondias mombin \\
\hline 40 & Tucumã & Astrocaryum aculeatum \\
\hline 41 & Tucumã-i & Astrocaryum acaule \\
\hline 42 & Ubaia & Eugenia patrisii \\
\hline 43 & Umari & Poraqueiba sericea \\
\hline 44 & Urucum & Bixa orellana \\
\hline 45 & Uxi & Endopleura uchi \\
\hline
\end{tabular}


Among the 30 NTFP reported by IBGE for the Amazon, Brazil nut collection and rubber extraction are the two most important ${ }^{5}$ as they together provide incomes to a large number of forest communities (Ferreira 2008). Generally, during summer, from November to March, there is collection of Brazil nut in the forest, while during winter, from April to October there is extraction of rubber. Table 4 shows the annual work calendar for ten families in Acre.

Table 4 | Annual work calendar

\begin{tabular}{|c|c|c|c|c|c|c|c|c|c|c|c|c|}
\hline FAM & JAN & FEB & $M A R$ & $A P R$ & MAY & JUN & JUL & $A \cup G$ & SEP & $O C T$ & NOV & $D E C$ \\
\hline 1 & 口 & 口 & $\boldsymbol{D} \Delta$ & $\Delta>0$ & 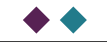 & $\Delta \bullet$ & 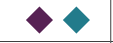 & $\diamond$ & $\diamond$ & $\square>0$ & & 口 \\
\hline 2 & a & 口 & 口 & 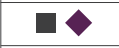 & $\bullet<0$ & 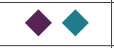 & 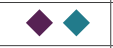 & $\diamond$ & $\Delta \Delta\rangle$ & - & 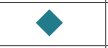 & 口 \\
\hline 3 & 口 & 口 & $\Delta 0$ & $\diamond$ & $\square<$ & 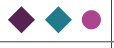 & $\Delta \bullet \bullet$ & $\diamond$ & $\nabla$ & $\square>00$ & 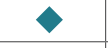 & $\diamond$ \\
\hline 4 & $\mathbf{a}$ & 口 & $\boldsymbol{D} \boldsymbol{\Delta}$ & $\square$ & $\nabla$ & $\Delta \bullet \bullet$ & 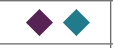 & $\diamond$ & 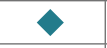 & $\square>00$ & $\nabla$ & $\diamond$ \\
\hline 5 & 口ם & 口 & $\nabla \Delta$ & 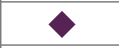 & 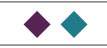 & $\Delta \bullet \bullet$ & $>$ & $\diamond$ & $\square \diamond \bullet$ & $>0$ & 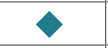 & 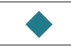 \\
\hline 6 & - & 口 & 口0 & $\nabla>$ & $\diamond<0$ & $\Delta \bullet \bullet$ & 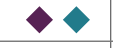 & $\Delta \bullet$ & - & $\square>$ & $\diamond$ & $\square$ \\
\hline 7 & - & - & 口0 & $\Delta \gamma$ & 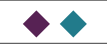 & 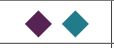 & $\phi$ & $\Delta \bullet$ & 口 & $>0$ & $\Delta$ & $\square$ \\
\hline 8 & 口 & 口 & $\nabla \Delta$ & 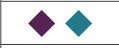 & $\Delta \bullet$ & 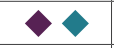 & $>$ & $\diamond$ & $\Delta \bullet$ & $\square$ & 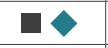 & $\square$ \\
\hline 9 & 口 & 口 & $\nabla \Delta$ & $\diamond$ & 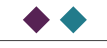 & $\Delta \bullet$ & $\bullet \bullet$ & $\diamond$ & $\square$ & $>0$ & $\square>0$ & $\mathbf{\square}$ \\
\hline 10 & - & - & 口잉 & $\diamond$ & 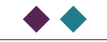 & $\diamond \bullet$ & 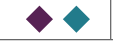 & $\diamond$ & 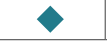 & $>0$ & $\diamond$ & 口 \\
\hline
\end{tabular}

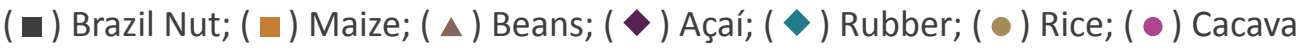

Source: adapted from Rocha (2002)

There is noted lack of information concerning the productivity and yield distribution across Amazonia. The only comprehensive work that models productivity and yield distribution across the biome was done through the project "Amazon Ecoservices". ${ }^{6}$ Throughout this project using interviews and focus groups with extractivists from Acre and Pará altogether with spatially explicit modelling it was estimated productivity of two NTFPs namely rubber and Brazil nut. In this work we report the estimates of the project referring to its project Report (Soares Filho, Carvalho Ribeiro et al 2015).

\section{BRAZIL NUT}

The Brazil nut tree (Bertholletia excelsa) produces one of the main seeds (Brazil nut) commercially harvested in rainforest ecosystems (Peres, Baider et al. 2003, Nunes, Soares-Filho et al. 2012, SEAPROF 2014). The next set of figures show the IBGE data on production (in ton) and value of production (in US\$ converted from real at 2,36 using the 2015 average rate). These values are not weighted by the forest area of the municipality, as it is likely that there is a market of NTFP across the municipalities, in which nuts produced in one municipality might enter the market in other municipality.

The mean annual production per municipality over the last 20 years (from 1994 to 2013) ranged from 0 (municipalities depicted in white) to 1,900 tones. Figure 3 shows the higher mean values in the municipalities (shaded in red) within Pará, Acre, Amazonas and Rondônia states, which produced, on average, from 1,000 to 1,900 tons of Brazil nut per year. There are municipalities producing, on average, 100 to 1,000 tons (shaded from orange to yellow). Lower production occurs, in general, in the municipalities at the biome's fringe (municipalities shaded in white producing less than a ton) and in the municipalities shaded from dark to light blue (average production between 1 and 100 tons). 


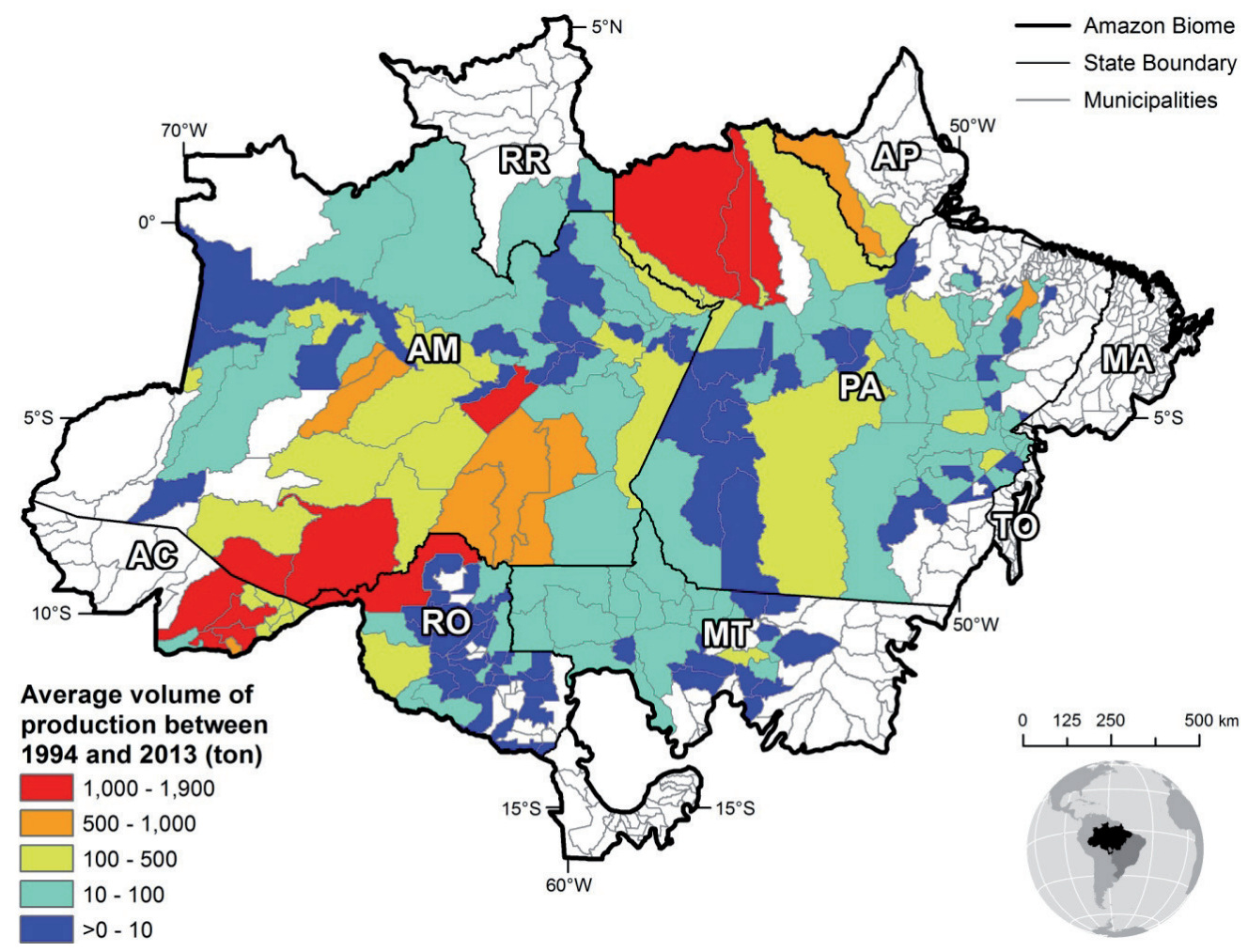

Figure 3 | Average volume of production between 1990 and 2013 (ton).

Source: Soares Filho; Carvalho Ribeiro et al. (2015).

The total value of production of Brazil nut, per municipality, ranges from US\$ 1 to US\$ 1 million. Notice that the municipalities with higher mean production (shaded in red) are also the ones with higher mean production values (Figure 4) (Soares Filho, Carvalho Ribeiro et al. 2015).

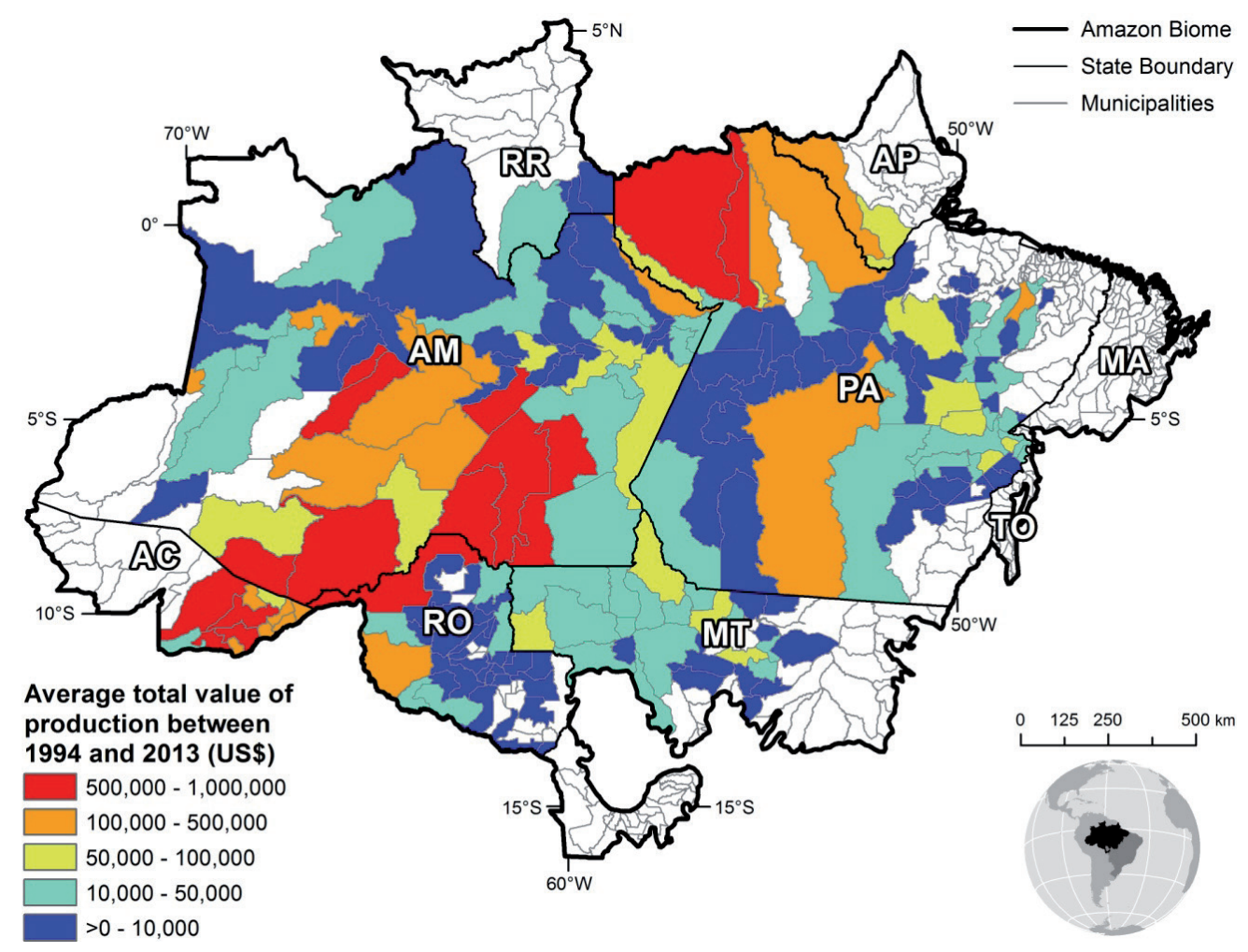

Figure 4 | Average total value of production between 1994 -2013 by municipality.

Source: Soares Filho, Carvalho Ribeiro et al. (2015). 
The mean annual values hide a huge variability. For example, in 2013 the production of Brazil nut in the Amazon municipalities ranged from 0 to a maximum of 3,700 ton. The value paid to producer also varies in different Amazonian states (Table 4).

Table 4 | Brazil nut maximum price (US\$) per kg of unshelled nuts between 2013 and 2015 used as price paid to producer in different states.

\begin{tabular}{|c|c|}
\hline Estate & Market (US\$) price per kg Cooperative \\
\hline Acre & 1.42 \\
\hline Amapá & 1.42 \\
\hline Amazonas & 1.77 \\
\hline Pará & 1.85 \\
\hline Maranhão & 0.85 \\
\hline Mato Grosso & 0.85 \\
\hline Tocantins & 0.85 \\
\hline Rondônia & 0.85 \\
\hline
\end{tabular}

Source: Soares Filho, Carvalho Ribeiro et al. (2015).

Brazil nut yields in the vast majority of areas (99\%) of the Brazilian Amazon situate between 0 to $30 \mathrm{~kg}$ per ha-1year-1, although there are locations where yields can reach $152 \mathrm{~kg}$ per ha ( $1 \%$ of the biome) (Table 5).

Table 5 | Brazil nut yields.

\begin{tabular}{|c|c|}
\hline Brazil nut yield $(\mathrm{kg} / \mathrm{ha})$ & Brazilian Amazon \\
\hline Minimum & 0.00 \\
\hline Maximum & 30.00 \\
\hline Mean & 8.19 \\
\hline Variance & 57.92 \\
\hline Standard deviation & 7.41 \\
\hline
\end{tabular}

Source: Soares Filho, Carvalho Ribeiro et al. (2015)

The annual rents of Brazil nut, presented as the Equivalent Annual Annuity (EAA), range from US\$ 0 to 46ha-1year-1 (Figure 5), with average rents of US\$ 5.05 ha-1year-1 (Table 6).

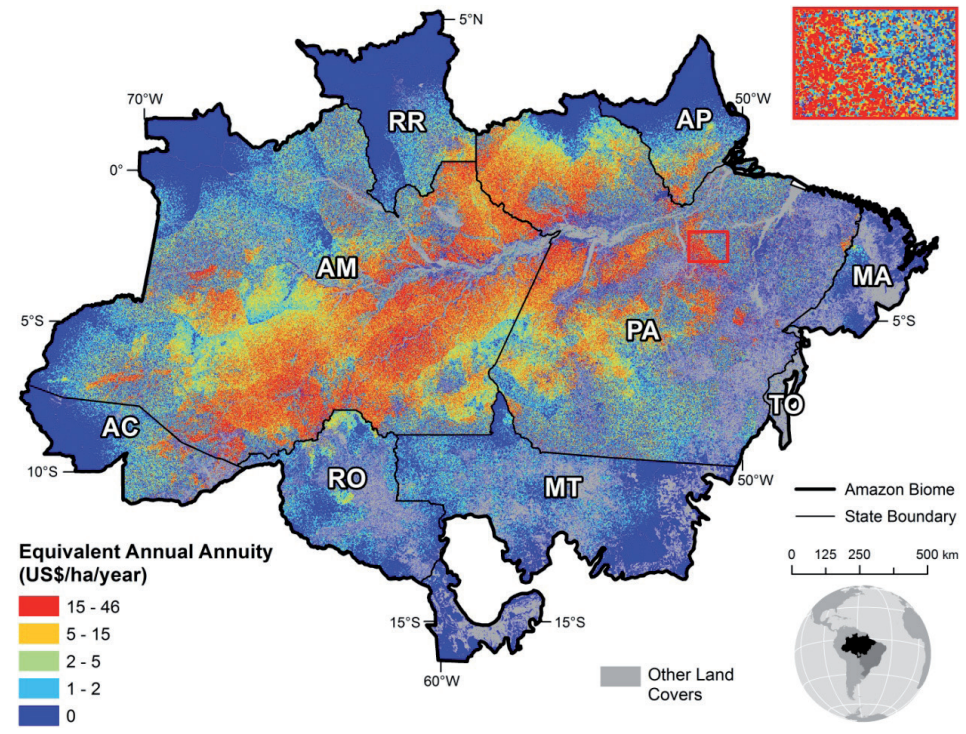

Figure 5 | Equivalent Annual Anuity for Brazil nut.

Source: Soares Filho, Carvalho Ribeiro et al. (2015). 
Table 6 | Brazil nut EAA.

\begin{tabular}{|c|c|}
\hline Rent Brazil nut & Brazilian Amazon \\
\hline Minimum & 0.00 \\
\hline Maximum & 46.00 \\
\hline Mean & 5.05 \\
\hline Variance & 56.24 \\
\hline Standard deviation & 7.49 \\
\hline
\end{tabular}

Source: Soares Filho, Carvalho Ribeiro et al. (2015)

\section{$R U B B E R$}

Hevea brasiliensis is the main source of natural rubber in the world (Soares Filho, Carvalho Ribeiro et al. 2015). The natural rubber has numerous applications with uses that go beyond 50 thousand objects; hence, it is one of the highest applicability products in industry. Paradoxically the rubber market is very dependent on the automobile (tiers) industry that consumes 80 to $90 \%$ of the rubber extracted in Brazil (SEAPROF 2014).

Natural rubber (not derived from petroleum) can be gathered either in native forests or in forest plantations, thus having two different production systems and production chains. In the Amazon, the prevalent system is the rubber tapping in native forests by the traditional extractivism system. Currently, rubber tapping in the Amazon still constitutes an income source for livelihoods of 5 to 10 thousand families, mainly located in Acre and Amazonas states (IBGE 2015). In the last 20 years (1994-2013), the mean total production, by municipality ranged from 1 to 400 ton (Figure 6). The higher mean values of production occurred in states of Amazonas, Acre, and Rondônia. Southern part of Amazonas and Acre also reached the higher mean total production values with a maximum of US\$360 thousand (Figure 7).

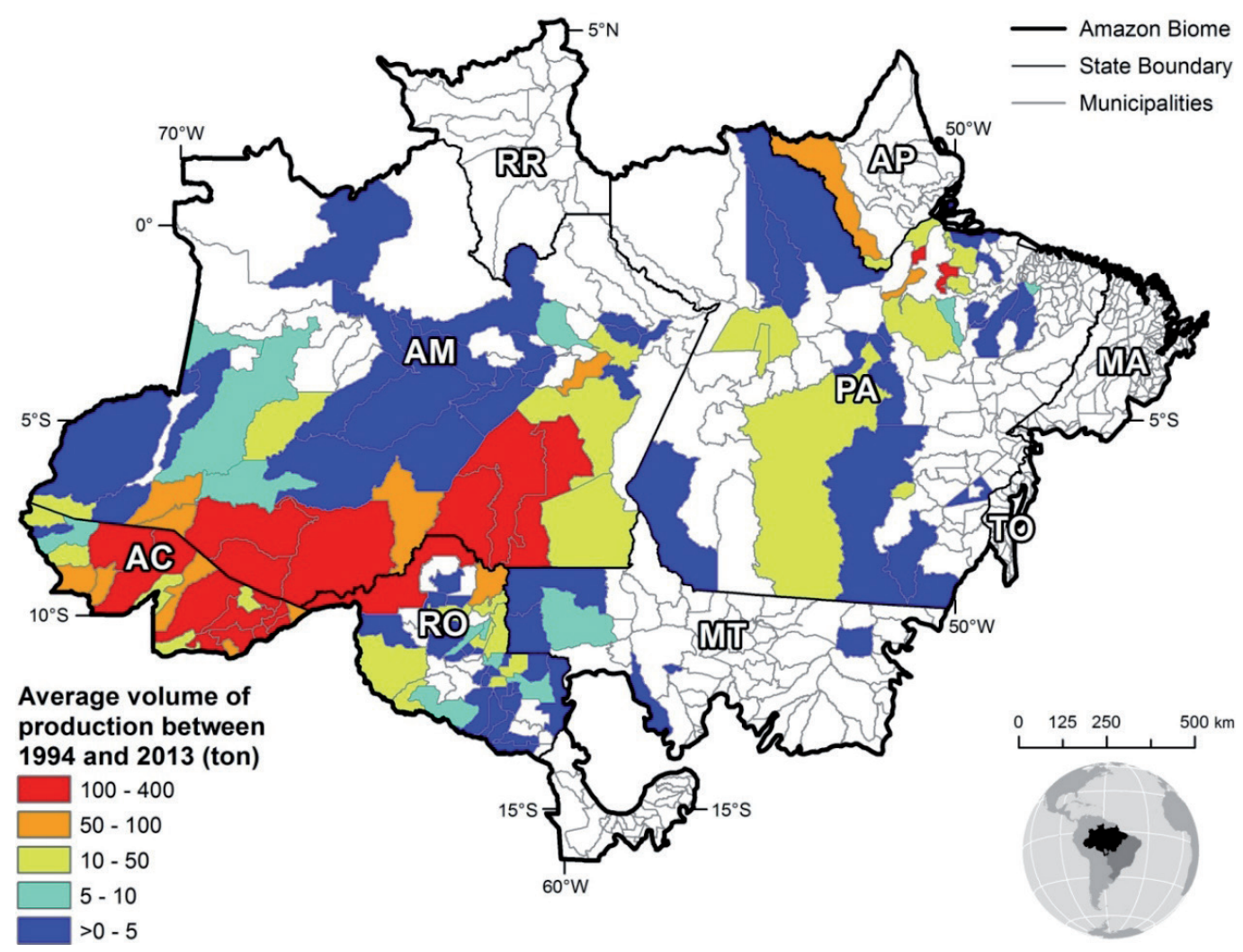

Figure 6 | Mean total production by municipality from 1990 to 2013

Source: IBGE (2015). 


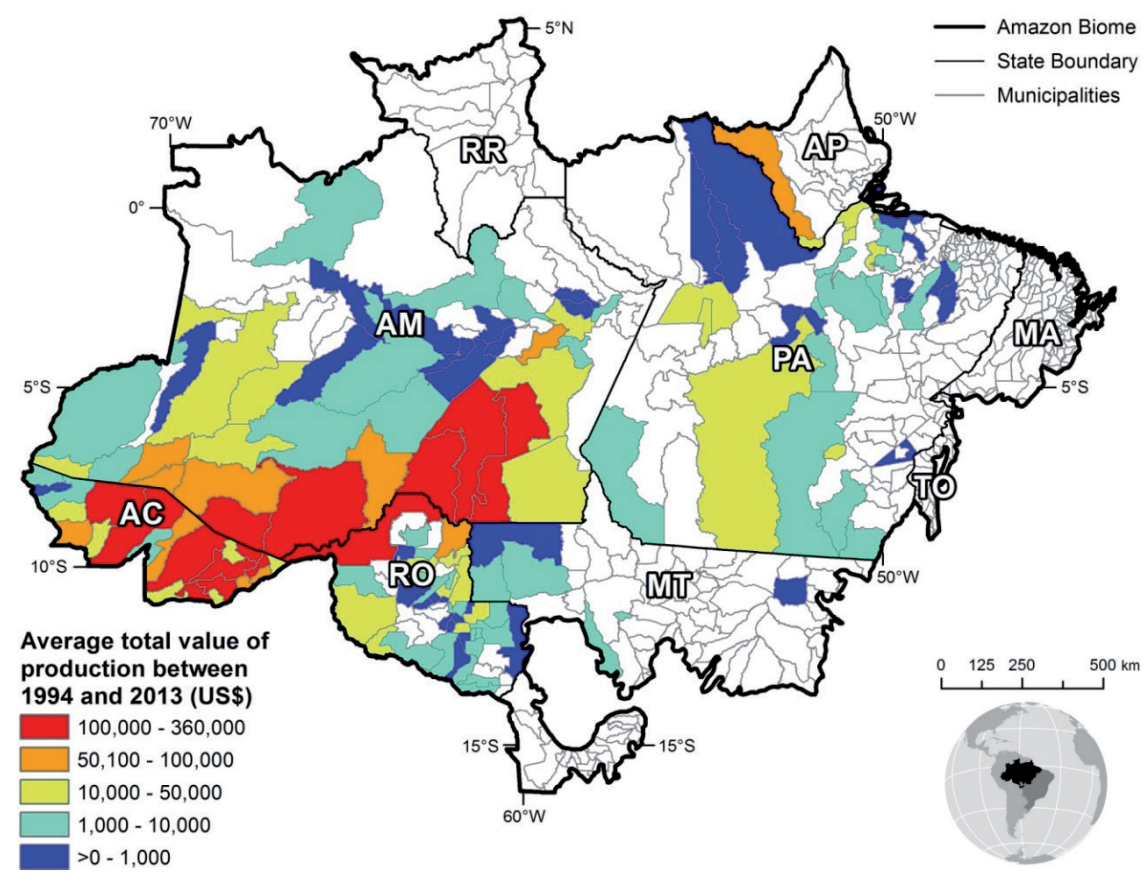

Figure 7 | Average total value of production (1994-2013).

Source: Soares Filho, Carvalho Ribeiro et al. (2015).

As in the case of Brazil nut, the average annual production for rubber hides a great annual variability. In 2013, only four municipalities (one in Acre and 3 in Amazonas) produced a maximum of 300 tons of rubber. The production of rubber ranged from 50 to 100 tons but the majority of the municipalities in the Brazilian Amazon had no production at all (Table 7).

Table 7 | Rubber yields for the Brazilian Amazon.

\begin{tabular}{|c|c|}
\hline Rubber yield $(\mathrm{kg} / \mathrm{ha})$ & Brazilian Amazon \\
\hline Minimum & 0.00 \\
\hline Maximum & 14.00 \\
\hline Mean & 3.28 \\
\hline Variance & 4.84 \\
\hline Standard deviation & 2.20 \\
\hline
\end{tabular}

Source: Soares Filho et. al. (2017)

As in the case of Brazil nut, the price paid to extractivists varies much depending on the year/season. According to Soares Filho et al (2015) the maximum price paid to extractivists by the cooperatives in the period 2013 to 2014 (Table) from the CONAB dataset.

Table 8 | Price paid to producer.

\begin{tabular}{|c|c|}
\hline State & US\$ per $\mathrm{kg}$ \\
\hline Acre & 0.80 \\
\hline Amapá & 1.09 \\
\hline Amazonas & 1.09 \\
\hline Pará & 1.21 \\
\hline Maranhão & 1.09 \\
\hline Mato Grosso & 1.25 \\
\hline Tocantins & 1.09 \\
\hline Rondônia & 1.12 \\
\hline
\end{tabular}

Source: Soares Filho et. al. (2017) 
The areas in red in Figure 8 show the locations with highest EAA. Rubber extraction in the Amazon is not profitable in areas of low productivity even with subsidies to guarantee a minimum price to rubber tappers. In the presence of governmental subsidies, rents average US\$ 0.56 ha-1year-1, varying from 0 to US\$ 6.13 ha-1 year-1 (Figure 8, Table 9).

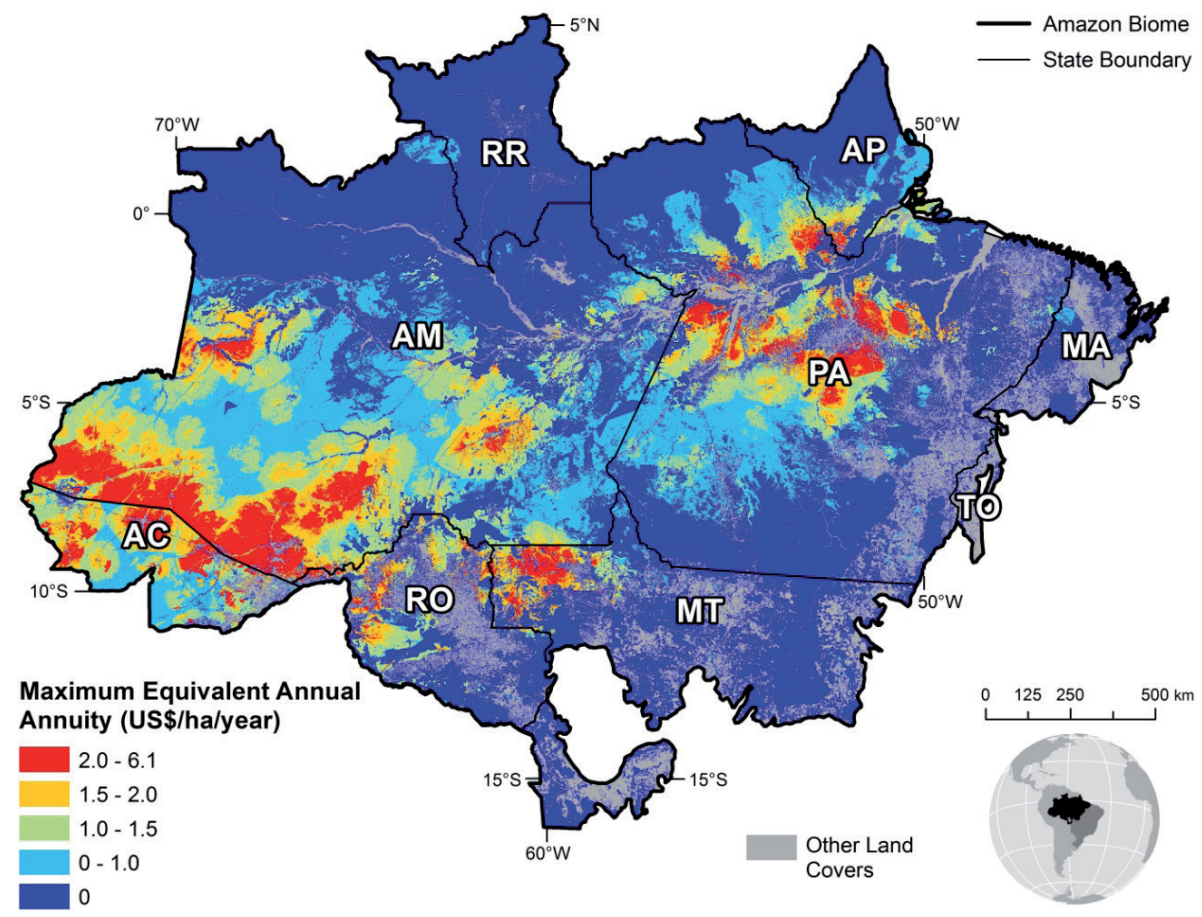

Figure 8 | EAA for rubber extraction.

Source: Soares Filho et. al. (2017).

Table 9 | Rents for rubber.

\begin{tabular}{|c|c|}
\hline Rents $(\mathbf{U S} \mathbf{S} / \mathrm{ha})$ & Brazilian Amazon \\
\hline Minimum & 0.00 \\
\hline Maximum & 6.13 \\
\hline Mean & 0.56 \\
\hline Variance & 0.57 \\
\hline Standard deviation & 0.76 \\
\hline
\end{tabular}

Source: Soares Filho et. al. (2017).

\subsection{MULTI SCALE GOVERNANCE FOR ENHANCED SOCIOBIODIVERSITY CHAINS IN AMAZONIA AND CERRADO BIOMES}

This work aimed at gathering data on the socio-ecology of extractivist landscapes in Brazil for exploring possible multi scale governance able to implement enhanced sociobiodiversity chains. We estimate 43 and 58 NTFPs for Amazon and Cerrado respectively (see an extensive list of the products of Amazon and Cerrado in ANEXE 1). Although there is a vast repertoire of empirical data for characterizing sociobiodiversity in Brazil this body of literature is mostly case study driven, focusing on a very limited number of products and using different methodological approaches. Therefore, although there is a robust research legacy meaningful comparison are very challenging.

So far we have a fragmented view of extractivist dynamics at the biome scale. There is thus the need to upscale from the socio ecology of individual NTFP to the biome scale encompassing a variety of products and its associated livelihoods. The new Legal Framework on Brazilian Biodiversity (Law 13,123), 
provides for access to genetic heritage, protection and access to associated traditional knowledge and the sharing of benefits for the conservation and sustainable use of biodiversity. This Law by the Federal Government (May 20, 2015) replaces the old national legislation, Provisional Measure 2186-16 / 2001. This Law acknowledges Traditional Ecological Knowledge (TEK) to traditional communities such as indigenous peoples, quilombolas, and family farmers.

In Brazil, Governmental bodies (e.g. ICMBIO, CONAB) universities and research institutes and the work by Non Governmental institutions have been active on safeguarding traditional knowledge and Brazilian genetic heritage. In the Amazonas state alone the number of communities assisted by incomegenerating social programs such as the Bolsa Floresta (PBF) - the largest Payment for Environmental Services (PES) program in tropical forests in the world- has been developing since 2008.

According to Fundação Amazônia Sustentável (FAS 2016), in 2015 alone more than 9 thousand families received benefits from income generation programs which often require community engagement through workshops, meetings surveys involving mapping and other data collection instruments for improving resource management. Similarly, in the Cerrado biome the sustainable management of NTFPs particularly Pequi has been explored for decades. Many possibilities come from the production of NTFPs and its derivatives, including the manipulation of other products. For example the Kalunga quilombola women group, besides producing and marketing the pequi and indaiá oils, produce pequi (dry pequi pulp) and traditional tingui soap (Magonia sp.). Similarly, the women's groups of the Jequitinhonha Valley (MG), in addition to produce and commercialize the vegetable oils of macaúba, pequi and ruffão make traditional soaps using macaúba oil.

Also, the group of women from Santa Rita do Novo Destino (GO) have been implementing agroforestry systems with the use of the Gueroba palm intercropped with other oilseeds such as black sesame and sunflower. These agroforestry products are gathered into cooperatives, rural and indigenous communities, technicians and other types of organizations that wish to collect in a sustainable way these NTFPs. The pequi is undubtably part of the traditions of the people of the cerrado and its consumption has also spread to other regions, including being marketed in large cities. However, its exploitation is still carried out in an extractive way, with few commercial cultivation initiatives.

Exception is a producer from Mato Grosso, who transformed almost $60 \%$ of its 90 ha property into a large pequizal, with more than 50,000 feet. According to Oliveira W.L de; Aldicir, S. (2010), usually the collection of the pequi is carried out in the extractivist lands themselves, in extractive reserves, sustainable use reserves, national or state forests or in third-party properties, where some owners work in partnership with the extractivists asking part of the production in return.

The conservation of the native species of the cerrado and Amazon become therefore of extreme importance, Several communities have already joined in cooperatives, many of them intermunicipal or even interstate, in order to provide greater value and diversity of the products that the two major biomes in Brazil presents. There are also several research and development projects conducted by organizations such as Embrapa, Emater, and several NGOs such as "The central of the Cerrado", "The cooperative of the small agroextractive producers of Lago do Junco - COPPALJ (MA)", (MA / TO), "Extractivist producers of Esperantinópolis - COPAESP (MA)", "Association of Rural Women Workers of Lago do Junco and Lago Rodrigues - AMTR (MA)", "Fruta Sã - Indústria, Comércio e Exportação LTDA Promise of Future (Pirenópolis - GO)"," Community Development Association of Caxambu (GO) ", to cite a few examples.

Industry and agribusiness are direct users of this genetic heritage and traditional knowledge, mainly for the development of commercial products such as medicines, cosmetics, food, etc., and the government is also directly involved.

Many of these communities also act in the buffer zones of many state and federal parks, further protecting these areas, or even as resistance to large producers to deprive the use of babaçu coconut 
palms (ATMR). Another good example is the community of Fruta Sã ${ }^{8}$ that harvest fruits in extractive areas but also manage new plantations into a domestication process Through organic management Fruta sã promotes partnerships with other economic enterprises of similar character in the states of Tocantins, Maranhão and next to the indigenista work center. ${ }^{9}$

The work developed so far received the Prize Chico Mendes in 2004, from the Ministry of the Environment, Brazil bank (Banco do Brasi) as well as the Foundation Social Technology Award, in the 2005 edition. Recently an international prize by United Nations was awarded to the collection process of sempre vivas ${ }^{10}$. There are therefore several initiatives and organizations that work for enhancing sociobiodiversity that created chains for specific products. However, many initiatives still act in a very incipient way and still have not reached a production and market that guarantee its social, environmental and economic sustainability. It also seems that acting on a product by product basis hampers the view of the whole socio ecological systems of extactivist landscapes. In addition to the previous, these initiatives from a bottom up perspective are dispersed and scatered across the vast areas of the two biomes and there is not a coordinated broad scale view of the extractivism in the Amazonia and Cerrado.

\section{DISCUSSION AND CONCLUSION}

This work aimed at assessing the dynamics of NTFP in two important biomes such as Amazon and Cerrado. We aimed at looking at sociobiodiversity at the biome scale exploring the diversity of NTFPs in each biome. The reason underlying the the goal of this paper was the awareness that each NTFP is part of a livelihood to which often contribute several NTFPs altogether with small scale farming and off farm labor (see table with the example from Acre).

Our approach extended well beyond the focus individual products to instead build a view of Amazon and Cerrado extractivist landscapes. We argue that this vision of the whole is much bigger than the sum of the parts. The problem is that the data available at the biome scale is scarce this hampering the vision and the potentialities of the sociobiodiversity at the biome scale. In our view this issue needs addressing. So far there is not the vision of sociobiodiversity of the whole biome comprising the diversity of NTFPs and its associated livelihoods.

The vast majority of the work so far focuses on a per product basis. This critique holds true for research agencies, governmental bodies (IBGE, MMA) and Non Governmental Organizations. In our view this is hampering sociobiodiversity plans in Brazil to move forward. Indeed there is a vast number of products in Amazonia and Cerrado but higher level governmental organizations such as IBGE data sets and MMA socio biodiversity plan (MMA 2009) report on a byproduct basis. From a bottom up perspective also the work by NGOs often work on a product by product basis. In our view this work and reporting on a by NTFP basis brings difficulties to forge strategies to move towards sustainability.

Because we adopted the biome scale analysis this inevitably allows a comparison between Amazonia and Cerrado Biomes. While there is a higher number of NTFPs in Cerrado, the sociobiodiversity plan by the MMA only awards 2 of them (Pequi and Buriti). Using multi-level perspective, it is possible to analyze socio technical transitions to sustainability (Geels 2011). The multi-level perspective theory analyses the socio-technical landscape and how it can be influenced by various factors. Additionally, it shows how the socio-technical landscape can be changed through the adoption of niche innovations. In this case study we were able to list two types of policies that can be seen as socio technical landscapes initiatives. One of them is the National Sociobiodiversity plan by MMA (2009) and other is the Framework on Brazilian Biodiversity (Law 13,123). As far as niche innovations is concerned, although we listed a number of organizations working on successful initiatives to deal with sociobiodiversity products we cannot assess if those initiatives are able to build momentum in such a way they are likely to lead the system to a transition to a more sustainable state. 
We therefore argue that pressure is not put on extractivist Socio-technical regimes either in Amazon either in Cerrado. When pressure is put on regimes, it creates windows of opportunity for niche innovations. However, not all innovative technologies will succeed to become part and transform the new regime without outside influence. Some initiatives require some extra input from outside, such as finances, legislation or education. The problem is that neither the sociobiodiversity plan nor the new biodiversity law seem to provide such mechanisms in order to nurture the successful initiatives already occurring scattered across the two biomes. We call for a systematic analysis at the biome scale for better understand the role of vegetal extarctivist activities in Brazil.

\section{NOTES}

1 | Traditional communities that live near the river

2 | Traditional communities' descents from African slaves

3 | http://cmbbc.cpac.embrapa.br/socioeconomia.htm (accessed 25/03/2019)

4 | http://www.mma.gov.br/desenvolvimento-rural/sociobiodiversidade

5 | Açai is the NTFP from the Amazon generating the highest incomes in the states of Pará, Amazonas and Maranhão.

6 | https://csr.ufmg.br/amazones/

7 | The Equivalent Annual Annuity (EAA) approach is one of two methods used in capital budgeting to compare mutually exclusive projects with unequal lives.

8 | http://www.centraldocerrado.org.br/comunidades/frutasa/

9 | https://trabalhoindigenista.org.br/home/

10 | https://nacoesunidas.org/agricultura-tradicional-de-flores-sempre-vivas-pode-ser-1o-patrimonio-agricola-mundialbrasileiro/

\section{REFERENCES}

BEDÊ, L.C. 2005. Alternativas para o uso sustentado de sempre-vivas: efeitos do manejo extrativista sobre Syngonanthus elegantulus ruhland (Eriocaulaceae). Universidade Federal de Minas Gerais, Instituto de Ciências Biológicas. Dissertação de Mestrado. 184 p, 2005.

CARVALHO RIBEIRO, S. M., B. SOARES FILHO, W. LELES COSTA, L. BACHI, A. RIBEIRO DE OLIVEIRA, P. BILOTTA, A. SAADI, E. LOPES, T. O'RIORDAN, H. LÔBO PENNACCHIO, L. QUEIROZ, S. HECHT, R. RAJÃO, U. OLIVEIRA and C. CIOCE SAMPAIO. Can multifunctional livelihoods including recreational ecosystem services (RES) and non timber forest products (NTFP) maintain biodiverse forests in the Brazilian Amazon? Ecosystem Services, 31: 517-526, 2018.

FAS, F. A. S. Relatório de Atividades 2015. Relatórios de Gestão da FAS. Manaus. 8: 120, 2016.

FERREIRA, L. T. “A seringueira no Brasil.” Biotecnologia Ciência \& Desenvolvimento, 2008.

GEELS, F. W. The multi-level perspective on sustainability transitions: Responses to seven criticisms. Environmental Innovation and Societal Transitions, 2011. 1(1): p. 24-40, 2011.

GIULIETTI AM, WANDERLEY MGL, LONGHI-WAGNER HM, PIRANI JR \& PARRA LR. Estudos em sempre-vivas: taxonomia com ênfase nas espécies de Minas Gerais, Brasil. Acta bot. Bras. 10(2):329-377, 1996.

GIULIETTI N, GIULIETTI A, PIRANI JR \& MENEZES NL. Estudos em sempre-vivas: importância econômica do extrativismo em Minas Gerais, Brasil. Acta bot. Bras. 1(2):179-193, 1988.

GRANDIN, G. Fordlandia, Rocco, 2010.

HOMMA, A. K. O. Extrativismo, Biodiversidade e Biopirataria na Amazônia. EMBRAPA, Texto para Discussão 27, ISSN 1677-5473, 2008. 
HUMPHRIES, S., T. P. HOLMES, K. KAINER, C. G. G. KOURY, E. CRUZ AND R. DE MIRANDA ROCHA. "Are communitybased forest enterprises in the tropics financially viable? Case studies from the Brazilian Amazon." Ecological Economics 77: 62-73, 2012.

Instituto Terra Brasilis de Desenvolvimento Socioambiental - ITB / Centro Cape /SEBRAE / Mãos de Minas. Projeto Sempre-Viva: Perspectivas de seu Uso Sustentado. ITB, Belo Horizonte, 1999.

IBGE. Instituto Brasileiro de Geografia e Estatística. Produção vegetal (2015) Disponível em:<http://www.ibge. gov.br/home/estatistica/economia/pevs/2013/default.shtm>. Acesso em: 25 mar. 2019

IBGE. Instituto Brasileiro de Geografia e Estatística. Produção vegetal (2015). Disponível em:<http://www.ibge. gov.br/home/estatistica/economia/pevs/2013/default.shtm>. Acesso em: 25 mar. 2019

IMPA. Frutos Nativos da Amazônia: comercializados nas feiras de Manaus - AMISBN: 9788521100737 Editora: INPA - Instituto Nacional de Pesquisas da Amazônia.Edição: 1ạa: 388 páginas, 2012.

MMA (2009). National plan for Sociobiodiversity chains Plano Nacional de Promoçao das Cadeias da Sociobiodiversidade (PNPSB). Ministry of Environment- MMA Ministerio Meio Ambiente (Brazil).

NUNES, F., B. SOARES-FILHO, R. GIUDICE, H. RODRIGUES, M. BOWMAN, R. SILVESTRINI AND E. MENDOZA. Economic benefits of forest conservation: assessing the potential rents from Brazil nut concessions in Madre de Dios, Peru, to channel REDD+ investments. Environmental Conservation doi:10.1017/S0376892911000671, 2012.

MOREIRA, F.C. Avaliação de sistemas de cultivo das sempre vivas Comanthera elegans (Bong.) L.R. Parra \& Giul. E C. bisulcata (Körn) L.R. Parra \& Giul. Universidade Federal dos Vales do Jequitinhonha e Mucuri, Programa de Pós-Graduação em Produção Vegetal. Dissertação de Mestrado. 99p., 2010.

PERES, C. A. et al. Demographic Threats to the Sustainability of Brazil Nut Exploitation. Science 302(5653): 2112-2114, 2003.

PETERS, C. M., A. H. Gentry and R. O. Mendelsohn. “Valuation of an Amazonian rainforest.” Nature 339: 655-656, 1989.

Rocha, E. Aspetos ecológicos e socio-econômicos do manejo de Euterpe precotoria Mart (Açaí) em áreas extrativistas no Acre, Brasil. Mestrado, Universidade de S. Paulo, 2002.

SEAPROF. Diagnóstico da Cadeia de Valor da Borracha, Secretaria de Estado de Extensão Agroflorestal e Produção Familiar-SEAPROF, Governo do Estado do Acre, 2014.

SEAPROF. Diagnóstico das cadeias de valor da castanha do Brasil, Secretaria de Estado de Extensão Agroflorestal e Produção Familiar - SEAPROF, Governo do Estado do Acre, 2014.

SCATENA, V. L.; CARDOSO, V. A.; GIULIETTI, A. M. Morfoanatomia de espécies de Blastocaulon Ruhland (Eriocaulaceae). Acta Botanica Brasílica, Porto Alegre, v. 13, p. 29-41, 1999.

SCHMIDT IB. Etnobotânica e ecologia populacional de Syngonanthus nitens: sempre-viva utilizada para artesanato no Jalapão, Tocantins. Universidade de Brasília, Instituto de Ciências Biológicas. Tese de Mestrado. 91 p., 2005.

TICTIN T. The ecological implications of harvesting non-timber forest products. Journal of Applied Ecology, 41 (1): 11-21, 2004.

SOARES FILHO, B., S. CARVALHO RIBEIRO, L. LIMA, W. COSTA, A. RIBEIRO, F. MERRY, W. GOMES, D. OLIVEIRA, I. LORENZINI AND H. RODRIGUES. Economic Valuation of Changes in the Amazon Forest Area: Value maps for Timber and Non Timber Forest Products (NTFP). Centro Sensoriamento Remoto https://csr.ufmg.br/amazones/ wp-content/uploads/2017/05/Report_NonTimber.pdf, 2015.

WUNDER, S., A. ANGELSEN AND B. BELCHER. Forests, Livelihoods, and Conservation: Broadening the Empirical Base. World Development 64, Supplement 1(0): S1-S11, 2014. 